be some provision for leisure-time activities where children could play and make a noise. In some new blocks of flats there should be a room available which children could use as a play centre. As a nation we were not doing an effective job with and for teenagers. Parents did not seem able to manage their teenage boys and girls, particularly girls. Mothers were not able to get on with their teenage daughters-could not moke friends with them; that was why there were so many 'beyond control' and 'care and protection' cases coming into the courts.

Mr. T. H. Hawkins, of Birfield, Ltd., suggested that while industry had a great deal to answer for in the way it had adversely influenced character formation in many young people, there had been great changes since the War, and to-day there were many employers who are not only concerned with their primary purpose of running successful businesses and making profits, but also recognize that their organizations have a social function to perform.

This point was supported by Miss F. Hornbrook, of the Ministry of Labour and National Service, who said that the firms where young people liked to work were those with good management, good working conditions, good training schemes and a good reputation in the neighbourhood.

In an address on young people and leisure, Sir Ben Bowen Thomas suggested that young people to-dey should be approached on the assumption that old social and economic divisions are on their way out, that community life is being articulated afresh, and that leisure activities are destined to hasten the process. Human relationships must conform increasingly to new social assumptions, social stratification counting for less and human association for more. "There is a threat only if we fail to humanize leisure. It holds an infinite promise of cultural creativeness and human happiness if.we succeed. If we are to be worthy of our dealings with young people who seem to be destined, in spite of great perils, to enter a world of fabulous possibilities, we must believe that leisure can be a means for cultured and civilized living for increasing numbers and that if our efforts are aimed at dealing with the spirits of young people in terms of their highest potential, we can help them to grow as human beings who will be equal to the moral requirements of their great estate".

\title{
OUTPUT OF CHEMICAL ENGINEERS IN BRITAIN
}

$\mathrm{R}$ EPLIES to a questionnaire sent by the Institution of Chemical Engineers to professors, heads of university departments, and principals of technical colleges in Great Britain regarding the present and future supply of chemical engineers and the difficulties experienced in obtaining suitable teaching staff, suggest that the country could provide 730 and 940 chemical engineers a year by 1959 and 1966, respectively, as compered with 277 in 1956.

The report "Scientific and Engineering Man-power in Great Britain" (H.M. Stationery Office, 1956) gives the total number of chemical engineers employed in Great Britain in 1956 as 1,500 and the total estimated number required by 1959 as 2,200 -an increase of 47 per cent. The survey shows that the output from the universities alone should be sufficient to meet this requirement. At the time of publication of the report on man-power, the actual total number of graduate and corporate members of the Institution of Chemical Engineers in Great Britain was approximately 2,100 , as compared with the figure of 1,500 given in the report.

The prospects in chemical engineering therefore appear to be good, but leave no grounds for complacency, especially when it is realized that the U.S.S.R., in relation to its population, trains three times as many professional engineers as the United Kingdom ("Engineering Education in the Soviet Union". Institution of Electrical Engineers, 1956). The estimates for 1959 appear to be somewhat optimistic, in view of the many difficulties in obtaining teaching staff described in the individual reports. These difficulties are real and widespread, and in general, rather worse in the technical colleges than in the universities.

The report on "The Supply and Training of Teachers for Technical Colleges" (H.M. Stationery Office, 1957) states that "for some years industry must be prepared to lose more than it may appear to gain.
The help which is given in such large measure during the evenings by industrial scientist and technologist is invaluable. With the rapid growth of day courses, however, their help during the day time will become increasingly necessary".

University teachers of chemical engineering are not generally very hopeful about the expansion of part-time day teaching by members of the staffs of industrial concerns. What is needed in the universities and colleges of advanced technology is the secondment from industry to teaching duties of qualified men with experience of part-time teaching in the evening, for periods of not less than six months, without loss of seniority.

There is justification for more interest and aupport from industry, not only in the problem of the shortage of teachers, but also in the extension of student apprenticeship schemes, coupled with study for university degrees ('thick sendwich'-type schemes); diplomas in technology (sandwich courses); and Higher National Certificates (part-time day release schemes). Student-apprentice schemes involving attendance at university courses are expensive-there is considerable capital investment in each candidate without guarantee of a return. The slow development of Higher National Certificate courses which are comparatively cheap from the point of view of industry suggests, however, that much more encouragement could be given than is at present apparent without incurring great expense.

A vigorous research school is an essential feature of a fully developed chemical engineering teaching department. It is doubtful, however, whether it is justifiable to retain at college for chemical engineering research a proportion as high as one-third of those with first degrees as the estimates for 1959 and 1966 indicate. In 1953, approximately 22 per cent of the members of the Institution of Chemical Engineers were employed on research and development. 